\title{
Exploring the significance of domestic investment for foreign direct investment in China: a city-network approach
}

Article

Accepted Version

Shia, S., Wall, R. and Pain, K. (2019) Exploring the significance of domestic investment for foreign direct investment in China: a city-network approach. Urban Studies, 56 (12). pp. 2447-2464. ISSN 1360-063X doi: https://doi.org/10.1177/0042098018795977 Available at https://centaur.reading.ac.uk/78441/

It is advisable to refer to the publisher's version if you intend to cite from the work. See Guidance on citing.

To link to this article DOI: http://dx.doi.org/10.1177/0042098018795977

Publisher: Sage

All outputs in CentAUR are protected by Intellectual Property Rights law, including copyright law. Copyright and IPR is retained by the creators or other copyright holders. Terms and conditions for use of this material are defined in the End User Agreement.

www.reading.ac.uk/centaur 
Central Archive at the University of Reading

Reading's research outputs online 


\title{
Exploring the Significance of Domestic Investment for Foreign Direct Investment in China: A City-Network Approach
}

\author{
Shuai Shi ${ }^{\mathrm{a}}$, Ronald Wall ${ }^{\mathrm{b}}$, Kathy Pain ${ }^{\mathrm{c}}$
}

a (Corresponding author) Real Estate \& Planning, Henley Business School, University of Reading, Whiteknights, Reading, United Kingdom. Tel: +44 (0) 7519204524. Email: s.shi@pgr.reading.ac.uk

${ }^{b} I H S$, Erasmus University, Rotterdam, 3000 BX, The Netherlands, and School of Economic and Business Sciences, University of the Witwatersrand (WITs), Johannesburg, South Africa. Tel: +31(0)104089715.Email:wall@ihs.nl

${ }^{c}$ Real Estate \& Planning, Henley Business School, University of Reading, Whiteknights, Reading, Berkshire, United Kingdom. Tel: +44 (0) 1183788175. Email:

k.pain@reading.ac.uk

\begin{abstract}
This paper uses a network approach and a negative binomial regression model (NBRM) to shed light on the association between Domestic Investment (DI) and Foreign Direct Investment (FDI) in interlinking Chinese cities in a space of flows. The empirical analysis is based on 2743 FDI and 9315 DI projects covering 77 Chinese cities. We address the question of what is the association between DI network measures and city attractiveness for FDI, and does the geographic distance of DI matter? While the physical distance of DI activity is found to have a negative association with FDI, city functional proximity and structural position in the DI network are found to have a positive association. We conclude that strategic policies to stimulate cross-territorial economic ties between Chinese cities should be advantageous in attracting inward foreign investment.
\end{abstract}

Keywords: Foreign Direct Investment, Domestic Investment, Cross-territorial Flow Networks, Core-Periphery, Cities, China

JEL classifications: F21, R12, R58 


\section{Introduction}

In the contemporary 'network society' facilitated by technological breakthroughs, urban agglomeration processes combined with 'city network' processes generate integrated markets and inter-city flows of labour, knowledge and capital (Castells, 1996; Alderson and Beckfield, 2004; Taylor, 2004). Both Jacobs (1969) and Castells (1996) emphasized agglomeration as a process involving flows between cities at diverse scales. Inter-city investments significantly develop and reproduce capital and labour pools and diffuse technology, knowledge etc. (Anderson, 1990; Barro, 1991). In the contemporary Chinese context, combining the accumulation and diffusion effects of capital mobility, Foreign Direct Investment (FDI) in particular, is associated with knowledge-intensive city networks and spillovers (Branstetter, 2006; Madariaga and Poncet, 2007; Lin et al., 2009), while Domestic Investment (DI) is seen as the cornerstone supporting market size and attracting foreign capital (Rama, 1993).

FDI is characterized by transnational practices, international exchange, complex ownership, long-term intentions, complementary capital, and export incentivization (De Mello, 1999; Kim and Seo, 2003). FDI by multinational corporations (MNCs) especially, contributes to transnational labour supply, trade, and the transfer of capital, high value-adding skills and technologies (Borensztein et al., 1998; Blomström and Sjöholm, 1999; Liu, 2008) and arguably has positive impacts on domestic firms, upgrading their capital stock (De Mello, 1999). FDI flows contribute to local growth specifically, because MNCs connect places to networks with specialized knowledge and innovation capacity that boost productivity through positive externalities and spillovers (Barba and Venables, 2004). The capital flow network across territories can therefore potentially contribute important insights into agglomeration economies and externalities associated with China's dramatic recent urbanisation, 'opening up' to foreign investment, and investment spatial concentration.

By 2012, China's FDI had surpassed that of the USA, reaching $18 \%$ of total inward investment (UNCTAD, 2013), making China the world's biggest host economy. Major flows of FDI into China are equipped with knowledge and production modes that can be transferred to domestic firms (Liu, 2008; Lin et al., 2009). The potential for FDI to add value to manufacturing production in China seems substantial (Dahlman and Aubert, 2001). Thus, there is no doubt that FDI has contributed significantly to China's rapid economic growth in recent decades. However, most previous studies focus on the crowd-in or crowd-out effect of FDI on DI by investment volume while few studies investigate the effect of DI on attracting 
FDI at city level through analysing the flow attributes of investments, which leaves a research gap in illuminating the association between FDI and DI using a network lens. The analysis in this paper addresses this research gap in intensifying Chinese connectivity to international investment flows by examining FDI agglomeration and its association with DI using a network analysis lens.

Three specific research questions are addressed: First, what are the roles and functions of different Chinese cities in the DI network? Second, beside agglomeration factors, what is the association between DI network measures and urban attractiveness for FDI, and does the geographic distance of DI matter? Third, what implications for development policies can be identified by adopting a network approach to city analysis in China? Accordingly, the paper first reviews the relationship between FDI and DI and introduces the methodological issues concerning the analysis of DI and FDI. Second, data, variables and the negative binomial regression model (NBRM) are specified. Third, the results on the contribution of DI network measures to the attraction of FDI are presented. Finally, based on the results, implications for the association between FDI and DI and urban development policies are discussed.

\section{Explaining the Urban FDI Agglomeration Process Using a City-Network}

\section{Approach}

Most studies focus on the effect of FDI on DI, known as the crowding-in or crowding-out effect of FDI. Based on empirical studies, the effect of FDI is still a matter of debate (see Borensztein et al., 1998; De Mello, 1999; Shan, 2002; Agosin and Machado, 2005; Haskel et al., 2007; Mutenyo et al.,2010; Al-Sadig, 2013). It is argued that FDI facilitates DI when FDI flows into underdeveloped sectors where domestic firms lack know-how, or into complementary value chains where foreign entry stimulates new upstream or downstream investment from domestic firms. While FDI tends to have a crowding-out effect on DI when it flows into competitive mature sectors or focuses on short-term ventures (Farla et al., 2016). In conclusion, the mixed effect of FDI on DI identified in previous studies highlights that domestic market conditions affect the relationship between FDI and DI.

Regardless of the disproportionate research focus on the effect of FDI on DI, a few studies have investigated the effect of DI on FDI. For example, by using an error correction model (ECM), Qi (2007) found a consistent positive effect of DI on FDI in developed countries, while the effect of DI on FDI is mixed in developing countries. Abu and Karim (2016) found that the effect of DI on FDI in Sub-Saharan Africa is not significant, however, a 
positive effect of FDI on DI is identified. In addition, by also using an ECM model, Tang et al. (2008) found little evidence of the effect of DI on FDI over time in China, which is in line with the findings of Abu and Karim (2016). However, there are some limitations to these studies. Most importantly, they ignore the network attributes of investment flows in explaining the relationship between FDI and DI in the current 'network society' (Castells, 1996). Secondly, these studies are limited to country-level analysis, which overlooks cities' importance in the world economy system. In addition, these studies regard firms' capital formation $^{1}$ as FDI and DI variables respectively, which may distort the significance of urban attractiveness for investors since high-value projects of powerful MNCs or domestic firms may take into account capital value formation. Using an inter-city network approach to explain the association between DI and FDI can fill these research gaps and inform future studies, particularly in cross-territorial capital mobility analysis.

Currently, there are two main approaches to explain agglomeration economies location factor analysis and network analysis. Location factors are perceived as endogenous drivers, such as local market size, labour pool, accessibility, industrial configuration, institutional context, high-tech clusters and cultural atmosphere (Florida, 2002). Krugman's (1991) 'new economic geography' proposed that the accumulation of these location factors associated with agglomeration economies lead to circular causation effects and persistent 'core-periphery' development. According to urban competitiveness literature, location factors are also critical in upgrading the industrial base, regarded as a core competitiveness factor underlying globalization processes (Porter, 1990; Turok, 2004). Furthermore, Boschma (2004) asserted that competition has extended from an organizational to a territorial level, arguing that, like firms, cities compete under conditions of strong economic specialization in similar markets where the impacts of FDI depend on the absorptive capability of cities. Specifically, human capital, financial markets, and technology gaps are critical location factors for cities to attract FDI (Glass and Saggi, 1998; Alfaro et al., 2004; Mahroum et al., 2008; Wall and van der Knaap, 2011).

On the other hand, widely-used location factor analysis seeking to explain development has been critiqued (Meijers, 2007). It is argued that markets stem intrinsically from social networks in which ideas, thoughts, innovations and learning are generated and shared; thus establishing linkages and collaboration networks can help firms to access external knowledge and boost urban productivity as an outcome (Powell et al., 1996; Mahroum et al., 2008). In conclusion, in the contemporary network society, network resources have become a strategic resource for economic actors to gain external 
complementary resources and knowledge (Dyer and Hatch, 2006; Huggins, 2010). Moreover, due to fuzzy production modes, different specializations and the division of labour, functional relations between cities tend to be more complementary than competitive, benefitting from scale economies, knowledge exchange and synergies (Capello, 2000). As Scott (2001) argued, globalizing cities in networks are now widely regarded as 'engines' of regional development (UN-Habitat, 2013: p. v) that should allow countries to move beyond Jacobs' 'transactions of decline' (Pain, 2012: p. 90).

Although there is an increasing number of empirical studies in China highlighting city positions in urban networks (see Taylor et al., 2014; Zhao et al., 2015; Pan et al., 2017), these studies focus on shedding light on city networks or on urban network connectivity itself but do not explore the association between city network positions and urban FDI agglomeration. In terms of explaining FDI using a network analysis lens, Kimino et al. (2012) pioneered work using the domestic 'Keiretsu' ${ }^{2}$ network to explain FDI in Japan and found that the domestic network is a significant influence on FDI inflows. They argued that the domestic network can provide pipelines for foreign investors to obtain knowledge and information. However, their domestic network was restricted to pre-existing Keiretsu member companies and their sales share in industrial sectors as opposed to dynamic direct DI flows across territories, leaving a void in investigating spatial characteristics and city network positions to explain the association between DI and FDI. Therefore, by combining city positionality analysis and the association analysis of DI and FDI, we postulate that city positions in China's DI network are significant for attracting FDI.

Nevertheless, this does not mean that the location and network approaches are mutually exclusive. In fact, they are complementary since networks (exogenous influence) and location factors (endogenous influence) coincide in cities (Wall and Stavropoulos, 2016). As Bathelt et al. (2004) argued, the agglomeration of economic activities is attributed to both local milieus where location factors are clustered to stimulate learning processes and outward linkages that provide external knowledge and information. Therefore, local milieus and external networks are complementary to each other in terms of knowledge diffusion and productivity gains (Johansson and Quigley, 2004). Accordingly, this paper tests the attractiveness for FDI conferred on Chinese cities by their positions in the established DI network and the policy implications of this. 


\section{Data and Methodology}

\section{The Data}

FDI data are sourced from the Financial Times fDi Markets database concerning ' greenfield $^{3}$, investments in which parent companies start up entirely new ventures in foreign countries by developing new operational facilities from the ground up. The reason for focusing on greenfield FDI, is that these projects can be considered a strong indicator of a city's attractiveness to foreign investors. Firstly, greenfield projects have high company profile requirements, and are normally carried out by influential MNCs. Secondly, when MNCs start up new operational branches, they explore domestic markets, which demands domestic capital connectivity (Nocke and Yeaple, 2007). Thirdly, greenfield projects directly facilitate the growth of local productivity and employment rather than mergers and acquisitions (M\&A) which only concern ownership changes (Agosin and Machado, 2005). Lastly, in contrast to international financial investments, greenfield projects tend to transfer core technology and production processes (Nocke and Yeaple, 2007).

Regarding data availability, DI data are only available for the year 2012. Since the analysis investigates the simultaneous association and subsequent relations between the established DI network and urban attractiveness for FDI, 2743 FDI projects in the period 2012 to 2014 are used to express the FDI attractiveness of Chinese cities. Thus, the relations between the established DI network in 2012 and FDI between 2012 and 2014 were examined. Data on Chinese city DI aggregates do exist. However, flows between Chinese cities are not readily available. For this reason, the study employs Bureau van Dijk (Orbis) corporate sharehold data ${ }^{4}$ between Chinese cities, as a proxy for DI flows between these cities. Headquarters in Chinese cities hold 51\% shares (or more) of subsidiary or affiliate firms in other cities, and are therefore arguably a good proxy for DI flows. The total number of projects is greater, thus, 9315 DI projects in 2012 are recorded. In addition, the research interest is not only in capital formation but also in positive externalities, such as technology, management modes, information and learning processes more generally. Therefore, the analysis focuses on the more reliable investment counts to shed direct light on FDI attractiveness.

The FDI and DI data are geographically coordinated to identify both source city nodes and destination city nodes and the physical distances between them, organized into respective 1-mode matrices used for network analysis. Lastly, built-up area ${ }^{5}$, population ${ }^{6}$ and GDP 
index ${ }^{7}$ are included to control for agglomeration effects, namely physical, labour and market size respectively (Marshall, 1920; Krugman, 2011). The control variables are derived from the National Bureau of Statistics of China (NBS). By cross-matching cities represented in all three databases, 77 Chinese cities ${ }^{8}$ remained to make a complete dataset.

\section{Measurement of Variables}

Social network analysis (SNA) is employed to complement the traditional focus on location factors, emphasizing the relations among economic agents and incorporating geographical coordinates to illustrate the pattern of networks and agglomeration (Borgatti and Foster, 2003). After multicollinearity testing, several network centrality measures are incorporated in the analysis. Network nodal centrality is divided into Indegree centrality and Outdegree centrality. Weighted Indegree concerns the total number of investments that a city receives to indicate cities' centripetal forces from source cities and 'prestige', or attractiveness. The FDI Weighted Indegree serves as the dependent variable. DI Weighted Indegree serves as one of the independent indicators. The DI Weighted Outdegree is a measure of the total number of outward DI projects of cities and an indicator of source cities' centrifugal forces to expand their controlling function in the DI network. It is a measure of the 'power' of cities to invest in other cities and to extend their connections in the DI network (Alderson and Beckfield, 2004). It is hypothesized that the more prestigious or powerful a city is in the DI network, the more FDI projects it will attract.

DI Indegree and Outdegree are unweighted measures estimating the number of cities that invest in a particular city on the one hand, and particular cities invested in on the other hand. These measures are representative of a city's relative degree of 'integration' within the DI network. It is hypothesized that the more a city is inwardly or outwardly connected in the DI network, the more FDI projects it will attract.

In addition to the nodal measures, Betweenness is used to investigate cities' structural positions within the DI network. The Betweenness indicator measures how often a node (city) appears on the shortest paths between other nodes in the network. It represents a 'broker' or 'gateway' function of a node in the network. It is hypothesized that the more 'bridged' a city is to other cities (and thereby strategically positioned in the network), the more it will be able to attract FDI. More formally, in equation (1),

$$
C_{B}(v)=\sum_{s \neq v \neq t \in V} \frac{\sigma_{s t}(v)}{\sigma_{s t}}
$$


where $\sigma_{s t}$ is total number of shortest paths from vertex s to vertex $\mathrm{t}$ and $\sigma_{s t}(v)$ is the number of shortest paths passing through vertex v.

Closeness, another structural measure, represents the sum of the geodesic functional distances to other nodes, i.e., the reciprocal of the sum of node's functional distances from all other nodes. It serves as a gauge for how closely related nodes are in a network, or how tightly linked they are within the network, and it is therefore an indicator of functional 'clustering'. Distinct from geographical clustering, Closeness thereby emphasizes the nodal relations' distance via virtual investment linkages. It is hypothesized that the more that cities are interlinked with each other in close network clusters, the more they will be able to attract FDI. More formally, in equation (2),

$$
C(x)=\frac{1}{\sum_{y} d(y, x)}
$$

(2)

Where $d(y, x)$ is the shortest functional distance between vertex $\mathrm{x}$ and all other vertices $\mathrm{y}$.

In addition, the overall structure characteristics of the DI network are estimated using density and degree-centralization. Density $C(V)$ is the total number of ties V divided by the total number of possible ties $V_{p}$, as formulated in equation (3). Degree centralization $C_{D}(G)$ represents the degree of inequality in the network $\mathrm{G}$ as a percentage of that of a perfect star network ${ }^{9} \mathrm{H}$ of the same size, as formulated in equation (4).

$$
C(V)=\frac{V}{V_{p}}, V_{p}=\frac{n *(n-1)}{2}
$$




$$
\begin{gathered}
v * \dot{i} \\
C_{D}\left(i-C_{D}\left(v_{i}\right)\right] \\
\dot{i} \\
i V \vee i \dot{i} \\
\sum_{i=1}^{i} i \\
C_{D}(G)=i
\end{gathered}
$$

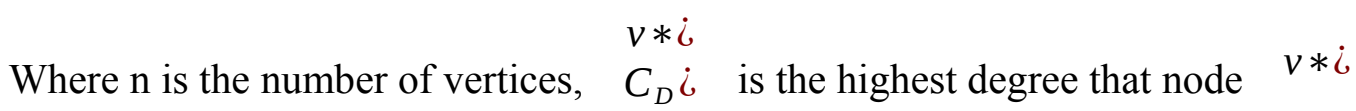
possesses.

Lastly, in addition to investigating the association between DI network positions and attractiveness for FDI, physical geographical influence is considered. We hypothesize that an increase in the geographic distance of a DI node's connections, will negatively influence its network performance and attractiveness for FDI. To test this, based on the geo-coordinates of cities in the DI network, the mean distance of all investments between a city and the other cities it is connected to is then taken as the observable variable. It is a measure of the geographical proximity of a city to all other cities within the DI network, whereby, it is hypothesized that the physical proximity of functional linkages will have a positive relation with the attractiveness for FDI. The average distance of node $\mathrm{x}, \mathrm{C}(\mathrm{x})$, is the quotient of the sum of the distance $\sum_{y} d(y, x)$ by the sum of linkage count $\sum_{y}(y, x)$, formulated in equation (5) as,

$$
C(x)=\frac{\sum_{y} d(y, x)}{\sum_{y}(y, x)}
$$

\section{The Model}

For the regression models, a distinction is made between types of network measures in terms of linkage and nodal types. These measures are conceptually different and they are therefore treated separately in the analysis. Firstly, Betweenness and Closeness are derived from the linkage structure of the network. They are derived from a dichotomized matrix of binary values (indicating the presence or non-presence of a linkage) and do not possess any directionality. Secondly, the nodal values concern weighted and directional measures of the 
vertices. Because the directionality concerns either inward flows or outward flows, these flows are treated separately.

Given the choice of models, as the classic count model, the Poisson regression model (PRM) estimates the number of investment linkages between source city $i$ and destination city $j$ and has a Poisson distribution with the conditional mean that is a function of several independent variables. The FDI number of the city $i$ is assumed to have a nonnegative integer value, the exponential of the independent variables is taken, which must be zero or positive. More formally in equation (6),

$$
P\left(Y_{i}=y_{i} \mid X_{i}\right)=\frac{e^{-\lambda_{i}} \lambda_{i}^{y_{i}}}{y_{i} !} ; \lambda_{i}=e^{\beta_{x i}}, i=1,2, \ldots n
$$

Parameter $\lambda_{i}$ can be seen as the dependent variable and concerns the probability of FDI, which depends on a vector of covariates $X_{i}$, which indicates the factors that possibly attract FDI. In the case of our first model these are X1 = indegree, X2 = weighted indegree, $\mathrm{X} 3$ = indegree distance. For our second model these are X1 = outdegree, $\mathrm{X} 2=$ weighted outdegree, $\mathrm{X} 3=$ outdegree distance. The third model concerns $\mathrm{X} 1=$ closeness and X2 = betweenness. For all three models the following controls are also used: X4 = GDP index, X5 $=$ total population, $\mathrm{X} 6=$ built urban area. $\beta$ is the regression coefficient of each $X_{i}$. An important assumption of the PRM is that it assumes that the equi-dispersion (the conditional variance should be equal to the conditional mean). Often, this condition is not satisfied and the dependent variable is over-dispersed. In order to correct for over-dispersion, the model is adapted to the NBRM. The NBRM allows the variance of the dependent variable to be greater than the mean value and captures the degree of over-dispersion (see Erdman et al. 2008, for adaption details). In addition, post-tests identified a better fit of the NBRM than the PRM. The countfit test shows that the NBRM is preferred over the PRM (Appendix Figure 3). Furthermore, a graphical representation showing both the Poisson distribution and the negative binomial distribution based on the mean (4.41) and dispersion of the count data (2.456), found that the negative binomial distribution has a better fit with the actual number of investments received in these cities (Appendix Figure 4). Therefore, we employ the 
NBRM to unveil the association of DI network characteristics with the urban attractiveness for FDI.

\section{Results}

\section{Spatial Distributions}

First, the characteristics of the geographical distribution of FDI and DI are illustrated. Regarding FDI, as shown in Figure 1, most top destination cities are located along the coastline, agglomerating at the Bohai Economic Rim (BER), the Yangtze River Delta (YRD) and the Pearl River Delta (PRD). On the other hand, some cities in western and central Chinese areas are becoming prominent such as Chengdu, Chongqing, Wuhan, Xi'an and Changsha, but not in a physically contiguous form as is the case for the three coastal regions. In contrast to FDI, as shown in Figure 2, although coastal areas are still the hotspots for DI, the geographical pattern of the DI network is stretched in a dispersed formation to the centre and the west, indicating more prominent cities in the DI network. Meanwhile, comparison between inward and outward investments shows that most cities play 'sinker" ${ }^{10}$ roles in the DI network. In addition, it is noticeable that four cities, Beijing, Shanghai, Shenzhen, and Guangzhou, have an overwhelming capacity in outward investment and play 'outsider' ${ }^{11}$ roles in the DI network, while other cities depend heavily on inward investment. In conclusion, the general geographical pattern of FDI and DI remains characterized by regional core-periphery disparity from the coastline to the inland area (see also Kanbur and Zhang, 2005; Li and Wei, 2010). However, significantly, Sichuan and Chongqing in the west and the Mid-Yangtze River (MYR) region in the centre are catching up, relieving the disparity between China's core and periphery regions.

\section{Insert Figure 1 here}

Insert Figure 2 here

\section{Network Performances}

Given the overall pattern, the DI network is a centralized network where power is concentrated in core cities and interactions between peripheral cities are sparse, reflecting the low density and high degree of centralization shown in Table 1. In order to clarify cities' positions, selected network measures are calculated and shown in Table 1. Given its attractiveness for FDI, Shanghai is the dominant city, followed by Beijing; notably, 22 of the 
top 30 FDI destinations are located along the coastline. Tianjin, as an industrial port and a less economically developed city than the top four, is in third position while Shenzhen drops to seventh position. Tianjin's surprising position may be attributable to its developed port functions as the fourth biggest port in the world and its newly-established free-trade zone (the only one in northern China). Given the DI network Weighted Indegree and Weighted Outdegree, it is found that the gap between China's core cities and other cities is much bigger in Outdegree, indicating that network extending power is concentrated in a limited number of cities. Given the Indegree and Outdegree, in addition to Beijing, Shanghai, Shenzhen and Guangzhou, more major cities such as Tianjin, Chongqing, Hangzhou and Nanjing are shown to be developing outward network relations, indicating that these cities are characterised by diversified outward partner profiles regardless of a smaller number of outward projects. Surprisingly, Nanning, the medium-sized capital city of the less developed Guangxi province, is a city with a strong outward orientation in comparison to similar Chinese cities, and is ranked in the top 10 for both Weighted Outdegree and Outdegree but is not ranked in the top 30 for either Weighted Indegree or Indegree. Nanning's outperformance in outward DI is mainly attributable to Sealand Security Company's ${ }^{12}$ DI profile which is characterised by diverse connections across cities instead of a concentration in just a few top cities such as Beijing, Shanghai etc. With respect to the structural positions expressed by Betweenness and Closeness, Beijing and Shanghai dominate the network as bridging ${ }^{13}$ cities and are the most functionally clustered cities in the DI network, followed by Shenzhen and Guangzhou. Lastly, as expected, the distant cities in the network are geographically located in the west and northeast of China.

In conclusion, the structure of the DI network is characterized by centralization processes. Regarding the four top cities, holding the second position in attracting FDI, Beijing holds the most powerful position in the DI network, followed by Shanghai and Shenzhen. Nevertheless, Guangzhou, which is regarded as one of China's four top cities, has relatively weak performance in attracting investment and in its bridging function in comparison to the other three cities. Despite a major disparity between these four cities and others, some major cities are catching up in circulating investment flows and capturing advantageous structural positions, such as Tianjin, Hangzhou, Chongqing, Chengdu, Nanjing and Wuhan. Amongst medium-size cities, Nanning is an outlier that nonetheless 'punches above its weight' in outward investment and clustering which give it an unexpected strategic network position. On the contrary, Suzhou ${ }^{14}$, which has high prestige in attracting FDI, has nonetheless failed to develop structural positions in the DI network, such as the controlling 
position and the bridging position. This result may be attributable to Suzhou's long-term openness to foreign capital and its established export processing zones, which lead to more than half of its industrial output being produced by foreign firms (NBS, 2015).

\section{Insert Table 1 here}

\section{NBRM Results}

Furthermore, as shown in Table 2, three models are specified, the first two are based on either inward or outward nodal measures, and the latter is based solely on linkage structure measures. In Model 1, Indegree is identified as a highly significant variable that contributes to attracting FDI, while Weighted Indegree is insignificant. Interestingly, the former is a measure of the number of cities that a city is connected to (i.e. integration), and holds significance over, while the latter which is a measure of tie-strength. Similarly, in Model 2, only Outdegree is identified as significant. It is revealed therefore that diversifying the partner city profile is more strategically important than accumulating investments in fixed partner cities for attracting FDI, which is in line with the arguments of Powell et al. (2001) and Mahroum et al. (2008). In addition, Indegree Distance has a significant negative association with city attractiveness for FDI, which means that potential recipient cities that are further from their DI origin cities are less capable of attracting foreign investment. Therefore, intertwined with the spatial clustering of FDI and DI distribution (as shown in Figures 1 and 2), the cities clustering in the YRD and PRD can generate more advantageous conditions in attracting FDI in comparison with cities located in the northeast and west. This finding indicates that distance still plays a role in the Chinese urban agglomeration process (Krugman, 1991). Nevertheless, in model 2, Outdegree Distance is not identified as being significant, which may indicate that outward DI is an investment form lacking spatial constraints. In Model 3, Closeness is highly significant in attracting FDI, which indicates that the more a city is functionally close to all other cities in the DI network, the more it is able to attract FDI (Capello, 2000). In addition, Betweenness is also highly significant in attracting FDI positively, which indicates that developing a city's strategic gateway function will improve cities' competitiveness in attracting FDI. This finding supports the relevance of Burt's structural hole theory for explaining FDI agglomerations, which highlights the significance of broker position in circulating knowledge and information (Burt, 2009).

Insert Table 2 here 
In conclusion, in contrast to Tang et al.'s finding, DI is found to be significant for FDI in China. In addition, in line with Kimino et al. (2012), the established domestic network plays an important role in attracting FDI. Specifically, bridging positions, regional clustering, and a diversified linkage profile in the DI network, can be expected to enhance the attractiveness of cities to foreign investors.

\section{Discussion}

This paper set out to fill a gap in the investigation of the association of DI and FDI using a network approach. Here we return to the three specific research questions initially posed.

First, what are the roles and functions of different Chinese cities in the DI network? The network analysis shows that the distribution of FDI and DI is associated with a pattern of agglomeration and economic gravity that is mainly located along the Chinese coastline and the Yangtze River. Four cities, Beijing, Shanghai, Shenzhen and Guangzhou, are shown to dominate the core in inter-city network relations, while other cities have relatively sparse linkages, indicating that the DI network is a centralised network space where network resources are concentrated in primary cities (Friedmann, 1986; Sassen, 1991). These four agglomerations have command and control network functions in circulating FDI as well as DI flows that indicate their global city-region status (Scott, 2001). Nevertheless, the Chinese DI network is not saturated. New linkages and significant network positions might be established, suggesting that there may be opportunities for upgraded network performance of more cities. For example, Nanning currently lacks network prestige due to its relatively undeveloped economy and small market relative to other cities of a similar size, however, both its extending outward linkage profile and its clustering performance may contribute to future improved urban attractiveness for FDI. The analysis therefore indicates that Chinese cities play different but complementary DI network roles that underpin diverse linkages between cities and increase their attractiveness for FDI.

Second, besides agglomeration factors, what is the association between DI network measures and urban attractiveness for FDI, and does the geographic distance of DI matter? The network analysis found several significant DI variables associated with urban attractiveness for FDI, especially Betweenness, Closeness and Degree measures. Therefore, the first hypothesis that the more prestigious or powerful a city is in the DI network, the more FDI projects it will attract, is rejected since the strength of inward and outward investment (investment volume), is not identified as significant in the model. However, the second 
hypothesis, that the more a city is inwardly or outwardly connected in the DI network (integration), the more FDI projects it will attract, is supported. In addition, the third and fourth hypotheses, that the more 'bridged' a city is to other cities and the more that cities are interlinked with each other in close network clusters, the more they will attract FDI, are verified, indicating the importance of cities' broker roles and regional clustering. Although the four top cities dominate in bridging and clustering functions, there is scope for other cities to develop broker roles in their regional markets as stronger links to core cities with a bridging role are built. This finding has particular relevance for major cities such as Hangzhou, Tianjin, Chengdu, Wuhan, Chongqing and Nanjing for domestic and foreign economic agents with ambitions to become more connected to the core Chinese cities, Shanghai, Beijing, etc., and for policy makers seeking to address China's uneven spaceeconomy structure. Functional clustering reinforces the position of cities in a regional market, and the development of network bridging roles is important in this because it assists city integration in foreign investment networks and the development of global production functions. The results from network analysis therefore lend support for Jacobs' (1984) thesis that interaction between cities supports economic expansion that benefits all cities and underpins linked urban growth. Resonating with Scott's (2001: p. 813) global city-region thesis also, the results illustrate how the emergence of synergistic inter-city network relations could potentially begin to reduce uneven regional development in China. Further research is required to explore how intercity network linkages could be strengthened by considering nuanced DI strategies, for example, relating to industrial classification differentiation, company characteristics, project objectives etc. In relation to the fifth hypothesis that the physical proximity of functional linkages will have a positive association with urban attractiveness for FDI, our analysis finds that geographical distance is not irrelevant for FDI attractiveness. There is no doubt that the relevance of physical distance is declining as a constraint for trans-local economic activities, however, the influence of physical proximity is limited to inward distance, suggesting the importance of geographical closeness to origin domestic cities for attracting FDI. Combined with identified functional Closeness, we can therefore speculate that the cities that are functionally clustered in the geographical centre of China, such as Zhengzhou, Wuhan, Changsha and Hefei, have significant opportunities for upgraded performance in the DI network and increased attractiveness for FDI projects.

Third, what implications for development policies can be identified by adopting a network approach to city analysis in China? The DI network pattern of cities is a potentially powerful resource that could allow China to guard against future economic "transactions of 
decline' (Pain, 2012). However, in order to exploit this resource, forward strategic economic and spatial planning and policies will be necessary. Although city DI-FDI interactions are already a significant contributor to China's contemporary growth, both forms of investment require coordinated regulatory and planning to promote an appropriate balance between them. For example, policies acknowledging and stimulating trans-local ties and diversified domestic partner profiles of cities are likely to be advantageous in attracting foreign inward investment. Policy for cities with established strong DI network positions should exploit this advantage in strategies to support sustainable economic growth by improving transaction market regulation and incentivising the development of business services. Policies for cities in less advantageous network positions should pinpoint and support emerging network interlinkages, for example, with broker cities and through noncompetitive intercity public-private actor cooperation in a regional context (Capello, 2000). Finally, contrary to Krugman's view that the new economic geography remains "utterly relevant to understanding developments in the world's fastest-growing economies' (2011: p. 16)", the results illustrate that city network analysis offers an important complementary analytical methodology by highlighting the complexity of contemporary location drivers in the fast-changing Chinese economic context.

\section{Notes}




\section{References}

Abu, N., and Karim, M. Z. A. (2016) The relationships between foreign direct investment, domestic savings, domestic investment, and economic growth: The case of Sub-Saharan Africa. Society and Economy in Central and Eastern Europe 38(2), 193-217.

Agosin, M. R., and Machado, R. (2005) Foreign investment in developing countries: does it crowd in domestic investment?, Oxford Development Studies 33(2), 149-162.

Alderson, A.S. and Beckfield, J., (2004) Power and position in the world city system. American Journal of Sociology, 109(4), pp.811-851.

Alfaro L., Chanda, A., Kalemli-Ozcan, S. and Sayek, S. (2004) FDI and economic growth: the role of local financial markets, Journal of International Economics 64(1), 89-112.

Al-Sadig, A. (2013) The effects of foreign direct investment on private domestic investment: evidence from developing countries, Empirical Economics 44(3), 1267-1275.

Anderson, D. (1990) Investment and economic growth, World Development 18(8) 1057-1079.

Barba, G. and Venables, A. J. (2004) Multinational Firms in the World Economy. Princeton University Press, Princeton, NJ.

Barro, R. J. (1991) Economic growth in a cross section of countries, Quarterly Journal of Economics 106(2), 407-443.

Bathelt, H., Malmberg, A., and Maskell, P. (2004) Clusters and knowledge: local buzz, global pipelines and the process of knowledge creation, Progress in Human Geography 28(1), 31-56.

Blomström, M. and Sjöholm, F. (1999) Technology transfer and spillovers: does local participation with multinationals matter? European Economic Review 43(4), 915-923. 
Borensztein, E., De Gregorio, J. and Lee, J. W. (1998) How does foreign direct investment affect economic growth? Journal of International Economics 45(1), 115-135.

Borgatti, S. P. and Foster, P. C. (2003) The network paradigm in organizational research: A review and typology, Journal of Management 29(6), 991-1013.

Boschma, R. (2004) Competitiveness of regions from an evolutionary perspective, Regional Studies 38(9), 1001-1014.

Branstetter, L. (2006) Is foreign direct investment a channel of knowledge spillovers? Evidence from Japan's FDI in the United States, Journal of International Economics 68(2), 325-344.

Capello, R. (2000) The city network paradigm: measuring urban network externalities, Urban Studies 37(11), $1925-1945$.

Castells, M. (1996) The Rise of the Network Society: The Information Age: Economy, Society and Culture, Volume I. Blackwell, Oxford.

Dahlman, C. J., and Aubert, J. E. (2001) China and the Knowledge Economy: Seizing the 21st Century. World Bank Publications, Washington DC.

De Mello, L. R. (1999) Foreign direct investment-led growth: evidence from time series and panel data, Oxford Economic Papers 51(1), 133151.

Dyer, J. H., and Hatch, N. W. (2006) Relation $\square$ specific capabilities and barriers to knowledge transfers: creating advantage through network relationships, Strategic Management Journal 27(8), 701-719.

Czinkota, M. R., \& Kotabe, M. (2000) Entering the Japanese market: a reassessment of foreign firms' entry and distribution strategies, Industrial Marketing Management, 29(6), 483-491.

Erdman, D., Jackson, L. and Sinko, A. (2008) Zero-inflated Poisson and zero-inflated negative binomial models using the COUNTREG procedure. Paper presented at the meeting of SAS Global Forum, March. SAS Global Forum, San Antonio, TX. 
Farla, K., De Crombrugghe, D., and Verspagen, B. (2016) Institutions, foreign direct investment, and domestic investment: crowding out or crowding in?, World Development 88, 1-9.

Florida, R. (2002) The economic geography of talent, Annals of the Association of American Geographers 92(4), $743-755$.

Friedmann, J. (1986) The world city hypothesis, Development and Change 17, 69-84.

Glass, A. J. and Saggi, K. (1998) International technology transfer and the technology gap, Journal of Development Economics 55(2), 369-398.

Haskel, J. E., Pereira, S. C., and Slaughter, M. J. (2007) Does inward foreign direct investment boost the productivity of domestic firms?, The review of economics and statistics $\mathbf{8 9 ( 3 ) , 4 8 2 - 4 9 6 .}$

Huggins, R. (2010). Forms of Network Resource: Knowledge Access and the Role of Inter $\square$ Firm Networks. International Journal of Management Reviews 12(3), 335-352.

Jacobs J. (1969) The Economy of Cities. Random House, New York.

Jacobs J. (1984) Cities and the Wealth of Nations. Random House, New York.

Johansson, B. and Quigley, J. M. (2004) Agglomeration and networks in spatial economies, in Florax, R. and Plane, D. A. (eds.) Fifty Years of Regional Science, pp. 165-176. Springer, Berlin.

Kanbur, R., and Zhang, X. (2005) Fifty years of regional inequality in China: a journey through central planning, reform, and openness, Review of Development Economics 9(1), 87-106.

Kim, D. and Seo, J. S. (2003) Does FDI inflow crowd out domestic investment in Korea?, Journal of Economic Studies 30(6), 605-622.

Kimino, S., Driffield, N. and Saal, D. (2012) Do Keiretsu really hinder FDI into Japanese manufacturing?, International Journal of the Economics of Business 19(3), 377-395. 
Krugman, P. (1991) Geography and Trade. MIT Press, Cambridge, MA.

Krugman, P. (2011) The new economic geography, now middle-aged, Regional Studies 45(1), 1-7.

Li, Y., and Wei, Y. D. (2010) The spatial-temporal hierarchy of regional inequality of China, Applied Geography 30(3), 303-316.

Lin, P., Liu, Z. and Zhang, Y. (2009) Do Chinese domestic firms benefit from FDI inflow? Evidence of horizontal and vertical spillovers, China Economic Review 20(4), 677-691.

Liu, Z. (2008) Foreign direct investment and technology spillovers: Theory and evidence, Journal of Development Economics 85(1), 176-193.

Madariaga, N. and Poncet, S. (2007) FDI in Chinese cities: Spillovers and impact on growth, World Economy 30(5), 837-862.

Mahroum, S., Huggins, R., Clayton, N., Pain, K. and Taylor, P. J. (2008) Innovation by Adoption: Measuring and Mapping Absorptive Capacity in UK Nations and Regions. National Endowment for Science, Technology and the Arts (NESTA), London.

Marshall, A. (1920) Principles of Economics: An Introductory Volume. Macmillan and Co. Ltd., London.

Meijers E. (2007) From central place to network model: Theory and evidence of a paradigm change, Tijdschrift voor economische en sociale geografie 98(2), 245-259.

Mutenyo, J., Asmah, E., and Kalio, A. (2010) Does foreign direct investment crowd-out domestic private investment in Sub-Saharan Africa, The African Finance Journal 12(1), 27-52.

Nocke, V., and Yeaple, S. (2007) Cross-border mergers and acquisitions vs. greenfield foreign direct investment: The role of firm heterogeneity, Journal of International Economics 72(2), 336-365.

Ouyang, P. and Fu, S. (2012) Economic growth, local industrial development and inter-regional spillovers from foreign direct investment: Evidence from China, China Economic Review 23(2), 445-460. 
Pain, K. (2012) Spatial transformations of cities: Global city region, mega-city region? In Derudder, B., Hoyler, M., Taylor, P. J. and Witlox, F. (eds.) International Handbook of Globalization and World Cities, pp. 83-93. Edward Elgar, Cheltenham.

Pan, F., Bi, W., Lenzer, J., and Zhao, S. (2017) Mapping urban networks through inter-firm service relationships: The case of China, Urban Studies 54(16), 3639-3654.

Porter, M. E. (1990) The competitive advantage of nations, Harvard Business Review 68(2), 73-93.

Powell, W. W., Koput, K. W. and Smith-Doerr, L. (1996) Interorganizational collaboration and the locus of innovation: Networks of learning in biotechnology, Administrative Science Quarterly, 116-145.

Qi, L. (2007) The relationship between growth, total investment and inward FDI: evidence from time series data, International Review of Applied Economics 21(1), 119-133.

Rama, M. (1993) Empirical investment equations for developing countries. In Servén, L. and Solimano, A. (eds.) Striving for Growth after Adjustment: The Role of Capital Formation (pp. 107-146). World Bank Publications, Washington DC.

Sassen, S. (1991) The Global City, New York, London, Tokyo. Princeton University Press, Princeton, NJ.

Scott, A. (2001) Globalization and the rise of global city-regions, European Planning Studies 9(7), 813-826.

Shan, J. (2002) A VAR approach to the economics of FDI in China, Applied economics 34(7), 885-893.

Tang, S., Selvanathan, E. A., and Selvanathan, S. (2008) Foreign direct investment, domestic investment and economic growth in China: A time series analysis, The World Economy 31(10), 1292-1309.

Taylor, P. J. (2004) World City Network: A Global Urban Analysis. Routledge, Abingdon.

Taylor, P., Derudder, B., Hoyler, M., Ni, P., and Witlox, F. (2014) City-dyad analyses of China's integration into the world city network, Urban Studies 51(5), 868-882. 
Turok, I. (2004) Cities, regions and competitiveness, Regional Studies 38(9), 1069-1083.

UNCTAD (United Nation Conference on Trade and Development) (2013) World Investment Report. United Nations Press, New York.

UN-Habitat (2013) State of the World's Cities 2012/13. Routledge, Abingdon.

Wall, R. S. and van der Knaap, G. A. (2011) Sectoral differentiation and network structure within contemporary worldwide corporate networks, Economic Geography 87(3), 267-308.

Wall, R S. and Stavropoulos, S. (2016) Smart cities within world city networks, Applied Economics Letters 23(12), 875-879.

Zhao, M., Liu, X., Derudder, B., Zhong, Y., and Shen, W. (2015) Mapping producer services networks in mainland Chinese cities, Urban Studies 52(16), 3018-3034. 


\section{Figures}

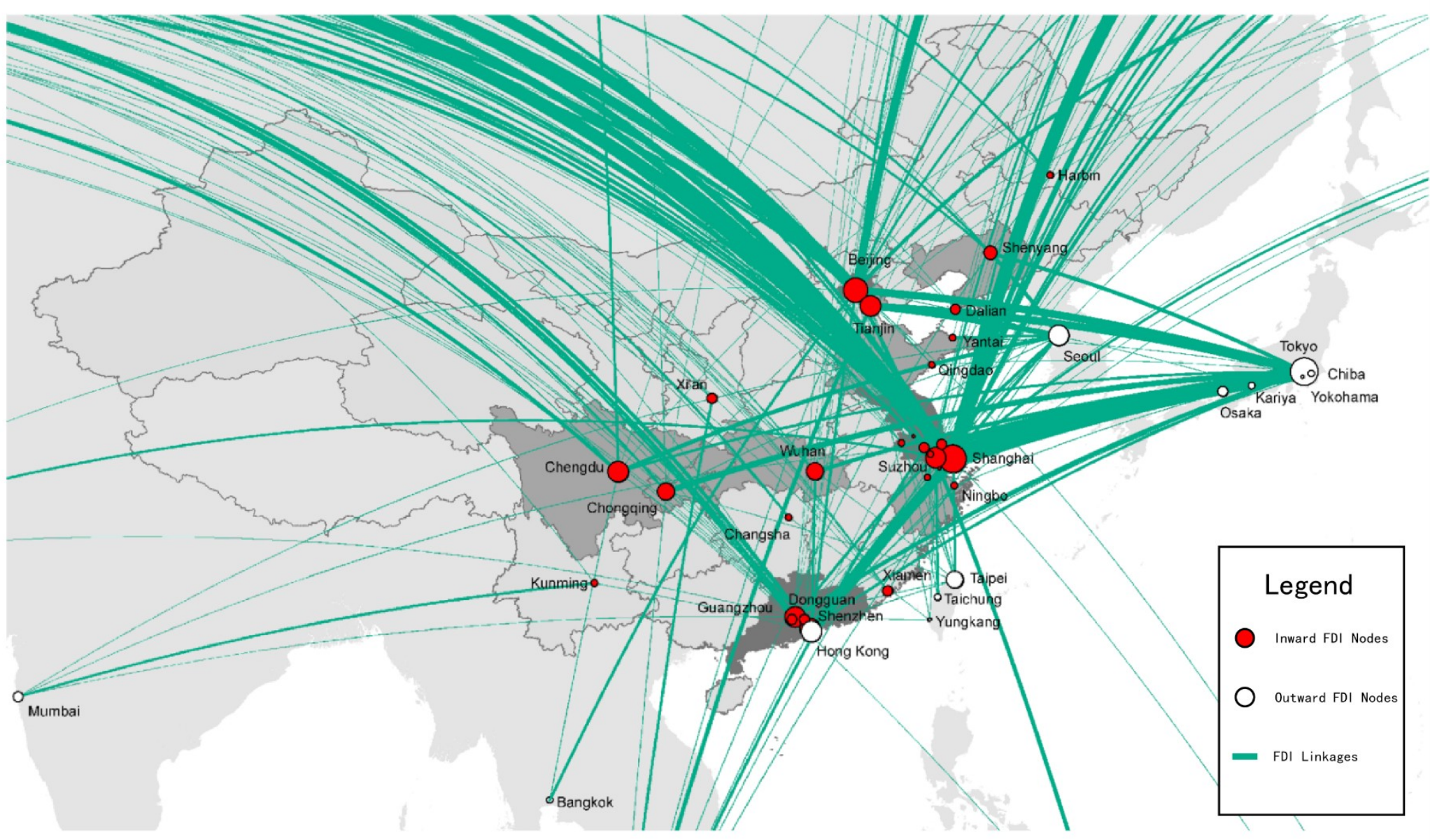

Note: The red nodes represent FDI destination cities. The white nodes represent FDI source cities. The size of the nodes represents the volume of FDI (range from Shanghai (799) to Harbin (12)), and the linkages represent the trajectory of FDI.

Figure 1. FDI distribution in China 


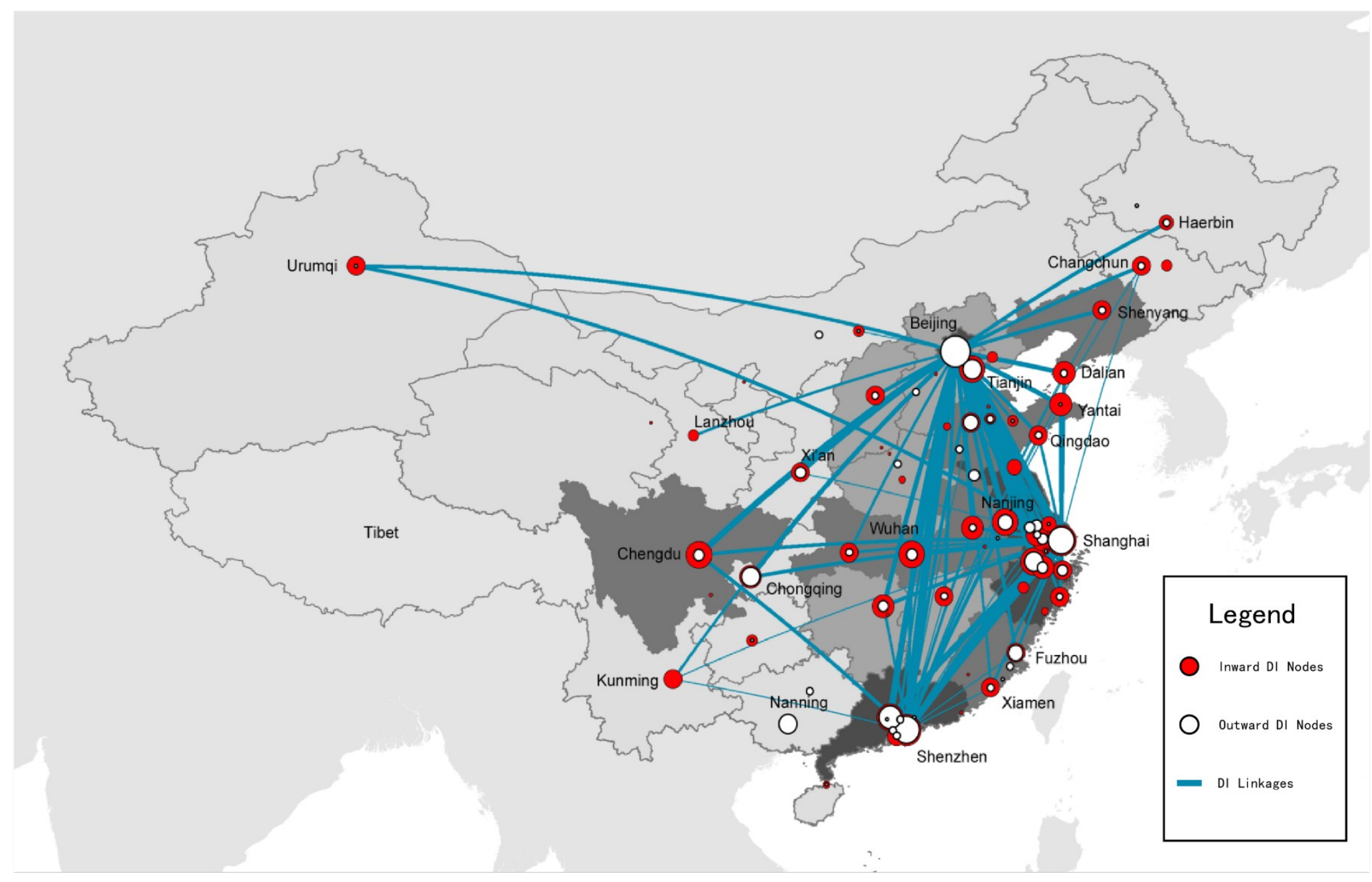

Note: The red nodes represent DI destination cities. The white nodes represent DI source cities. The size of the nodes represents the volume of DI (range from Beijing (3908) to Lanzhou (84)), and the linkages represent the trajectory of DI.

Figure 2. DI distribution in China 


\section{Tables}

\begin{tabular}{|c|c|c|c|c|c|c|c|c|c|c|c|c|c|c|c|c|}
\hline Rank & City & $\begin{array}{l}\text { FDI } \\
\text { Weight } \\
\text { ed } \\
\text { Indegr } \\
\text { ee } \\
\end{array}$ & City & $\begin{array}{l}\text { DI } \\
\text { Weight } \\
\text { ed } \\
\text { Indegr } \\
\text { ee } \\
\end{array}$ & City & $\begin{array}{l}\text { DI } \\
\text { Weight } \\
\text { ed } \\
\text { Outdeg } \\
\text { ree }\end{array}$ & City & $\begin{array}{l}\text { DI } \\
\text { Indegr } \\
\text { ee }\end{array}$ & City & $\begin{array}{l}\text { DI } \\
\text { Outdegre } \\
\text { e }\end{array}$ & City & $\begin{array}{l}\text { DI } \\
\text { Betweene } \\
\text { ss }\end{array}$ & City & $\begin{array}{l}\text { DI } \\
\text { Closene } \\
\text { ss }\end{array}$ & City & $\begin{array}{l}\text { DI } \\
\text { Distanc } \\
\text { e }\end{array}$ \\
\hline 1 & Shanghai & 799.00 & Beijing & $\begin{array}{l}1034.0 \\
00\end{array}$ & Beijing & $\begin{array}{l}3908.00 \\
0\end{array}$ & Beijing & 41 & Beijing & 69 & Beijing & 748 & Beijing & 1 & Urumqi & 3016 \\
\hline 2 & Beijing & 387.00 & $\begin{array}{l}\text { Shenzhe } \\
n\end{array}$ & $\begin{array}{l}861.00 \\
0\end{array}$ & Shangha & $\begin{array}{l}2978.00 \\
0\end{array}$ & Shangha & 39 & $\begin{array}{l}\text { Shangha } \\
\mathrm{i}\end{array}$ & 69 & $\begin{array}{l}\text { Shangha } \\
\mathrm{i}\end{array}$ & 681 & Shanghai & 1 & $\begin{array}{l}\text { Changchu } \\
\mathrm{n}\end{array}$ & 1850 \\
\hline 3 & Tianjin & 99.00 & $\begin{array}{l}\text { Shangha } \\
\mathrm{i}\end{array}$ & $\begin{array}{l}799.00 \\
0\end{array}$ & $\begin{array}{l}\text { Shenzhe } \\
\mathrm{n}\end{array}$ & $\begin{array}{l}2112.00 \\
0\end{array}$ & $\begin{array}{l}\text { Shenzhe } \\
\mathrm{n}\end{array}$ & 29 & $\begin{array}{l}\text { Shenzhe } \\
n\end{array}$ & 69 & $\begin{array}{l}\text { Shenzhe } \\
\mathrm{n}\end{array}$ & 386 & $\begin{array}{l}\text { Shenzhe } \\
\mathrm{n}\end{array}$ & 1 & Kunming & 1705 \\
\hline 4 & Guangzhou & 93.00 & Hangzho & $\begin{array}{l}450.00 \\
0\end{array}$ & $\begin{array}{l}\text { Guangzh } \\
\text { ou }\end{array}$ & 753.000 & $\begin{array}{l}\text { Hangzho } \\
\text { u }\end{array}$ & 26 & $\begin{array}{l}\text { Guangzh } \\
\text { ou }\end{array}$ & 68 & $\begin{array}{l}\text { Guangzh } \\
\text { ou }\end{array}$ & 176 & $\begin{array}{l}\text { Guangzh } \\
\text { ou }\end{array}$ & 0.99 & Haerbin & 1593 \\
\hline 5 & Suzhou & 93.00 & $\begin{array}{l}\text { Guangzh } \\
\text { ou }\end{array}$ & $\begin{array}{l}350.00 \\
0 \\
32900\end{array}$ & Tianjin & 108.000 & Chengdu & 25 & Tianjin & 38 & $\begin{array}{l}\text { Hangzho } \\
\text { u }\end{array}$ & 139 & Tianjin & 0.69 & Yinchuan & 1591 \\
\hline 6 & $\begin{array}{l}\text { Chengdu } \\
\text { Shenzhen }\end{array}$ & $\begin{array}{l}91.00 \\
90.00\end{array}$ & $\begin{array}{l}\text { Wuhan } \\
\text { Nanjing }\end{array}$ & $\begin{array}{l}329.00 \\
0 \\
303.00\end{array}$ & \begin{tabular}{|l} 
Hangzho \\
u \\
Chongqi
\end{tabular} & $\begin{array}{l}82.000 \\
81.000\end{array}$ & Nanjing & 24 & $\begin{array}{l}\text { Chongqi } \\
\mathrm{ng} \\
\text { Hangzho }\end{array}$ & 36 & $\begin{array}{l}\text { Tianjin } \\
\text { Chongqi }\end{array}$ & 137 & $\begin{array}{l}\text { Chongqi } \\
\text { ng } \\
\text { Hangzho }\end{array}$ & 0.68 & Lanzhou & 1433 \\
\hline 7 & Chongqing & 69.00 & & $\begin{array}{l}0 \\
283.00\end{array}$ & $\begin{array}{l}\text { ng } \\
\text { Nanning }\end{array}$ & 73.000 & Wuhan & 23 & u & 33 & $\mathrm{ng}$ & 111 & $\mathrm{u}$ & 0.66 & Chengdu & 1361 \\
\hline 8 & & 55.00 & Tianjin & & Fuzhou & 53.000 & Suzhou & 21 & Nanning & 31 & Jinan & 111 & Nanning & 0.64 & Shenyang & 1304 \\
\hline 9 & Nanjing & 48.00 & Suzhou & $\begin{array}{l}0 \\
248.00\end{array}$ & Nanjing & 47.000 & Wuxi & 21 & Nanjing & 28 & Nanjing & 79 & Nanjing & 0.63 & Guiyang & 1300 \\
\hline 10 & Wuxi & 40.00 & Hefei & $\begin{array}{l}0 \\
224.00\end{array}$ & Jinan & 40.000 & Hefei & 21 & $\begin{array}{l}\text { Fuzhou } \\
\text { Changsh }\end{array}$ & 26 & Haikou & 74 & $\begin{array}{l}\text { Fuzhou } \\
\text { Changsh }\end{array}$ & 0.62 & Haikou & 1290 \\
\hline 11 & Shenyang & 38.00 & Changsh & $\begin{array}{l}0 \\
222.00\end{array}$ & Changsh & 38.000 & \begin{tabular}{|l} 
Tianjin \\
Guangzh
\end{tabular} & 19 & & 22 & Wuhan & 62 & & 0.59 & Jinan & 1209 \\
\hline 12 & Kunshan & 34.00 & $\begin{array}{l}\text { a } \\
\text { Dalian }\end{array}$ & $\begin{array}{l}0 \\
212.00\end{array}$ & $\begin{array}{l}\text { a } \\
\text { Ningbo }\end{array}$ & 32.000 & & 18 & Jinan & 21 & Fuzhou & 50 & Jinan & 0.59 & Hohhot & 1192 \\
\hline 13 & Xi'an & 34.00 & Yantai & $\begin{array}{l}0 \\
210.00\end{array}$ & Xuzhou & 32.000 & Shaoxing & 18 & Ningbo & 19 & Ningbo & 48 & Ningbo & 0.58 & $\begin{array}{l}\text { Taiyuan } \\
\text { Chongqin }\end{array}$ & 1168 \\
\hline 14 & Hangzhou & 33.00 & Shaoxing & $\begin{array}{l}0 \\
201.00\end{array}$ & & 30.000 & Foshan & 18 & Xuzhou & 19 & Suzhou & 48 & Xuzhou & 0.58 & $g$ & 1151 \\
\hline 15 & Qingdao & 31.00 & Wuxi & $\begin{array}{l}0 \\
184.00\end{array}$ & Jiangyin & 27.000 & Ningbo & 17 & Suzhou & 17 & Xi'an & 45 & Suzhou & 0.57 & $\begin{array}{l}\text { Tangshan } \\
\text { Guangzho }\end{array}$ & 1146 \\
\hline 16 & Changzhou & 30.00 & Chongqi & $\begin{array}{l}0 \\
178.00\end{array}$ & Suzhou & 26.000 & & 17 & $\begin{array}{l}\text { Xi'an } \\
\text { Changzh }\end{array}$ & 17 & $\begin{array}{l}\text { Wuxi } \\
\text { Nanchan }\end{array}$ & 45 & $\begin{array}{l}\text { Xi'an } \\
\text { Changzh }\end{array}$ & 0.57 & $\mathrm{u}$ & 1144 \\
\hline 17 & Nantong & 30.00 & $\begin{array}{l}\text { ng } \\
\text { Urumqi }\end{array}$ & $\begin{array}{l}0 \\
173.00\end{array}$ & Wuhan & 25.000 & $\begin{array}{l}\text { Yantai } \\
\text { Chongqi }\end{array}$ & 17 & & 17 & I th o t & 43 & & 0.57 & Beijing & 1130 \\
\hline 18 & Xiamen & 30.00 & Ningbo & $\begin{array}{l}0 \\
172.00\end{array}$ & Changzh & 25.000 & & 16 & Wuhan & 16 & $\begin{array}{l}\text { Chengdu } \\
\text { Changzh }\end{array}$ & 43 & Wuhan & 0.57 & Shenzhen & 1112 \\
\hline 19 & Ningbo & 29.00 & Fuzhou & $\begin{array}{l}0 \\
162.00\end{array}$ & $\begin{array}{l}\text { ou } \\
\text { Shaoxing }\end{array}$ & 24.000 & Kunming & 16 & $\begin{array}{l}\text { Dalian } \\
\text { Nanchan }\end{array}$ & 16 & & 33 & $\begin{array}{l}\text { Dalian } \\
\text { Nanchan }\end{array}$ & 0.57 & \begin{tabular}{|l} 
Dalian \\
Shijiazhu
\end{tabular} & 1095 \\
\hline 20 & Dongguan & 28.00 & Qingdao & $\begin{array}{l}0 \\
159.00 \\
0\end{array}$ & Chengdu & 23.000 & $\begin{array}{l}\text { Urumqi } \\
\text { Fuzhou }\end{array}$ & $\begin{array}{l}16 \\
15\end{array}$ & $\begin{array}{l}\mathrm{g} \\
\text { Chengdu }\end{array}$ & $\begin{array}{l}15 \\
14\end{array}$ & $\begin{array}{l}\text { Foshan } \\
\text { Changsh } \\
\text { a }\end{array}$ & $\begin{array}{l}27 \\
26\end{array}$ & ghengdu & $\begin{array}{l}0.56 \\
0.56\end{array}$ & $\begin{array}{l}\text { ang } \\
\text { Ningbo }\end{array}$ & $\begin{array}{l}1094 \\
1085\end{array}$ \\
\hline
\end{tabular}




\begin{tabular}{|c|c|c|c|c|c|c|c|c|c|c|c|c|c|c|c|c|}
\hline 22 & Dalian & 25.00 & Xi'an & $\begin{array}{l}147.00 \\
0\end{array}$ & $\begin{array}{l}\text { Nanchan } \\
\mathrm{g}\end{array}$ & 23.000 & \begin{tabular}{|l} 
Changsh \\
a
\end{tabular} & 15 & $\begin{array}{l}\text { Changch } \\
\text { un }\end{array}$ & 14 & Xiamen & 20 & $\begin{array}{l}\text { Changch } \\
\text { un }\end{array}$ & 0.56 & $\begin{array}{l}\text { Zhongsha } \\
\text { n }\end{array}$ & 1067 \\
\hline 23 & $\begin{array}{l}\text { Changshu } \\
\text { Foshan }\end{array}$ & $\begin{array}{r}24.00 \\
21.00\end{array}$ & Taizhou & $\begin{array}{l}145.00 \\
0 \\
142.00\end{array}$ & $\begin{array}{l}\text { Wuxi } \\
\text { Dalian }\end{array}$ & $\begin{array}{l}21.000 \\
20000\end{array}$ & $\begin{array}{l}\text { Changzh } \\
\text { ou } \\
\text { Nanchan }\end{array}$ & 15 & $\begin{array}{l}\text { Zhengzh } \\
\text { ou }\end{array}$ & 14 & Shaoxing & 20 & $\begin{array}{l}\text { Zhengzh } \\
\text { ou }\end{array}$ & 0.56 & Tianjin & 1064 \\
\hline 24 & $\begin{array}{l}\text { Foshan } \\
\text { Changsha }\end{array}$ & $\begin{array}{l}21.00 \\
20.00\end{array}$ & $\begin{array}{l}\text { Nanchan } \\
\mathrm{g} \\
\text { Changch }\end{array}$ & $\begin{array}{l}142.00 \\
0 \\
135.00\end{array}$ & $\begin{array}{l}\text { Dalian } \\
\text { Changch }\end{array}$ & $\begin{array}{l}20.000 \\
20.000\end{array}$ & $\begin{array}{l}\text { Nanchan } \\
\mathrm{g}\end{array}$ & 15 & Wuxi & 13 & Xuzhou & 19 & Wuxi & 0.55 & Xi'an & 1055 \\
\hline 25 & Taicang & 17.00 & $\begin{array}{l}\text { un } \\
\text { Xiamen }\end{array}$ & $\begin{array}{l}0 \\
135.00 \\
0\end{array}$ & $\begin{array}{l}\text { un } \\
\text { Xiamen }\end{array}$ & 19.000 & $\begin{array}{l}\text { Xiamen } \\
\text { Taizhou }\end{array}$ & 15 & $\begin{array}{l}\text { Xiamen } \\
\text { Shaoxing }\end{array}$ & $\begin{array}{l}13 \\
12\end{array}$ & $\begin{array}{l}\text { Hefei } \\
\text { Shenyan } \\
\text { g }\end{array}$ & 18 & $\begin{array}{l}\text { Xiamen } \\
\text { Shaoxing }\end{array}$ & $\begin{array}{l}0.55 \\
0.55\end{array}$ & $\begin{array}{l}\text { Nantong } \\
\text { Lianyung } \\
\text { ang }\end{array}$ & $\begin{array}{l}1031 \\
1019\end{array}$ \\
\hline 27 & Hefei & 16.00 & Kunming & $\begin{array}{l}133.00 \\
0\end{array}$ & Putian & 19.000 & Haikou & 15 & Foshan & 12 & Dalian & 17 & Foshan & 0.55 & Qingdao & 1016 \\
\hline 28 & Zhengzhou & 15.00 & Shenyan & $\begin{array}{l}130.00 \\
0\end{array}$ & Taiyuan & 18.000 & Jinan & 14 & $\begin{array}{l}\text { Donggua } \\
\text { n }\end{array}$ & 12 & Kunming & 14 & $\begin{array}{l}\text { Donggua } \\
n\end{array}$ & 0.55 & $\begin{array}{l}\text { Donggua } \\
\text { n }\end{array}$ & 962 \\
\hline 29 & $\begin{array}{l}\text { Zhuhai } \\
\text { Harbin }\end{array}$ & $\begin{array}{l}12.00 \\
12.00\end{array}$ & $\begin{array}{l}\text { Yichang } \\
\text { Jinan }\end{array}$ & $\begin{array}{l}127.00 \\
0 \\
126.00 \\
0\end{array}$ & $\begin{array}{l}\text { Haerbin } \\
\text { Zhengzh } \\
\text { ou }\end{array}$ & $\begin{array}{l}18.000 \\
18.000\end{array}$ & \begin{tabular}{|l} 
Shenyan \\
g \\
Yichang
\end{tabular} & 14 & $\begin{array}{l}\text { Taiyuan } \\
\text { Putian }\end{array}$ & $\begin{array}{l}12 \\
12\end{array}$ & $\begin{array}{l}\text { Donggua } \\
\text { n } \\
\text { Taiyuan }\end{array}$ & 13 & $\begin{array}{l}\text { Taiyuan } \\
\text { Putian }\end{array}$ & $\begin{array}{l}0.55 \\
0.55\end{array}$ & $\begin{array}{l}\text { Wenzhou } \\
\text { Zhengzho } \\
\text { u }\end{array}$ & $\begin{array}{l}893 \\
858\end{array}$ \\
\hline
\end{tabular}

Density $=0.247$, Degree-centralization $=0.779$, Av-distance $=1.81$, Diameter $=3$.

Table 1. Top 30 cities in FDI and DI centrality 


\begin{tabular}{|c|c|c|c|}
\hline Variables & $\begin{array}{l}\text { Model } 1 \\
\text { (inward nodal) } \\
\text { FDI count (2012- } \\
2014 \text { ) }\end{array}$ & $\begin{array}{l}\text { Model } 2 \\
\text { (outward nodal) } \\
\text { FDI count (2012- } \\
2014 \text { ) }\end{array}$ & $\begin{array}{l}\text { Model } 3 \\
\text { (linkage } \\
\text { structure) } \\
\text { FDI count (2012- } \\
2014)\end{array}$ \\
\hline Indegree & $\begin{array}{c}0.0993 * * * \\
(0.0238)\end{array}$ & & \\
\hline Weighted Indegree & $\begin{array}{l}-0.000798 \\
(0.00128)\end{array}$ & & \\
\hline Indegree Distance & $\begin{array}{c}-0.000711^{* * *} \\
(0.000237)\end{array}$ & & \\
\hline Outdegree & & $\begin{array}{l}0.0327 * * \\
(0.0163)\end{array}$ & \\
\hline Weighted Outdegree & & $\begin{array}{c}0.00018 \\
(0.000243)\end{array}$ & \\
\hline Outdegree Distance & & $\begin{array}{l}-0.0000293 \\
(0.000246)\end{array}$ & \\
\hline Closeness & & & $\begin{array}{l}1.323 * * \\
(0.551)\end{array}$ \\
\hline Betweenness & & & $\begin{array}{l}0.00323^{* * *} \\
(0.000982)\end{array}$ \\
\hline GDP Index & $\begin{array}{l}0.0783^{* *} \\
(0.0385)\end{array}$ & $\begin{array}{c}0.062 \\
(0.0399)\end{array}$ & $\begin{array}{c}0.0805^{* *} \\
(0.04)\end{array}$ \\
\hline Total Population & $\begin{array}{l}-0.000243 \\
(0.00029)\end{array}$ & $\begin{array}{l}-0.000266 \\
(0.000358)\end{array}$ & $\begin{array}{l}-0.0000601 \\
(0.000304)\end{array}$ \\
\hline Built Urban Area & $\begin{array}{l}0.00187^{* *} \\
(0.000817)\end{array}$ & $\begin{array}{c}-0.001 \\
(0.00115)\end{array}$ & $\begin{array}{c}0.00081 \\
(0.000868)\end{array}$ \\
\hline Constant & $\begin{array}{l}-8.5^{* *} \\
(4.411)\end{array}$ & $\begin{array}{l}-6.427 \\
(4.544)\end{array}$ & $\begin{array}{l}-8.704 * \\
(4.573)\end{array}$ \\
\hline Pseudo R2 & 0.25 & 0.198 & 0.212 \\
\hline Observations & 73 & 73 & 73 \\
\hline
\end{tabular}

Robust standard errors in parentheses; ${ }^{* * *} \mathrm{p}<0.01,{ }^{* *} \mathrm{p}<0.05,{ }^{*} \mathrm{p}<0.1$.

Table 2. NBRM results 


\section{Appendix}

\begin{tabular}{|c|c|c|c|c|c|c|c|}
\hline PRM & $\mathrm{BIC}=$ & 89.105 & $\mathrm{AIC}=$ & 5.340 & Prefer & Over & Evidence \\
\hline \multirow[t]{3}{*}{ vs NBRM } & $\mathrm{BIC}=$ & -29.636 & $\operatorname{dif}=$ & 118.741 & NBRM & PRM & Very strong \\
\hline & $\mathrm{AIC}=$ & 4.126 & $\operatorname{dif}=$ & 1.213 & NBRM & PRM & \\
\hline & $\mathrm{LRX} 2=$ & 123.346 & prob $=$ & 0.000 & NBRM & PRM & $p=0.000$ \\
\hline
\end{tabular}

Note: AIC - Akaike's information criteria; BIC - Bayesian information criteria; LrX2 - likelihood-ratio X2.

Figure 3. Tests and model fit statistics

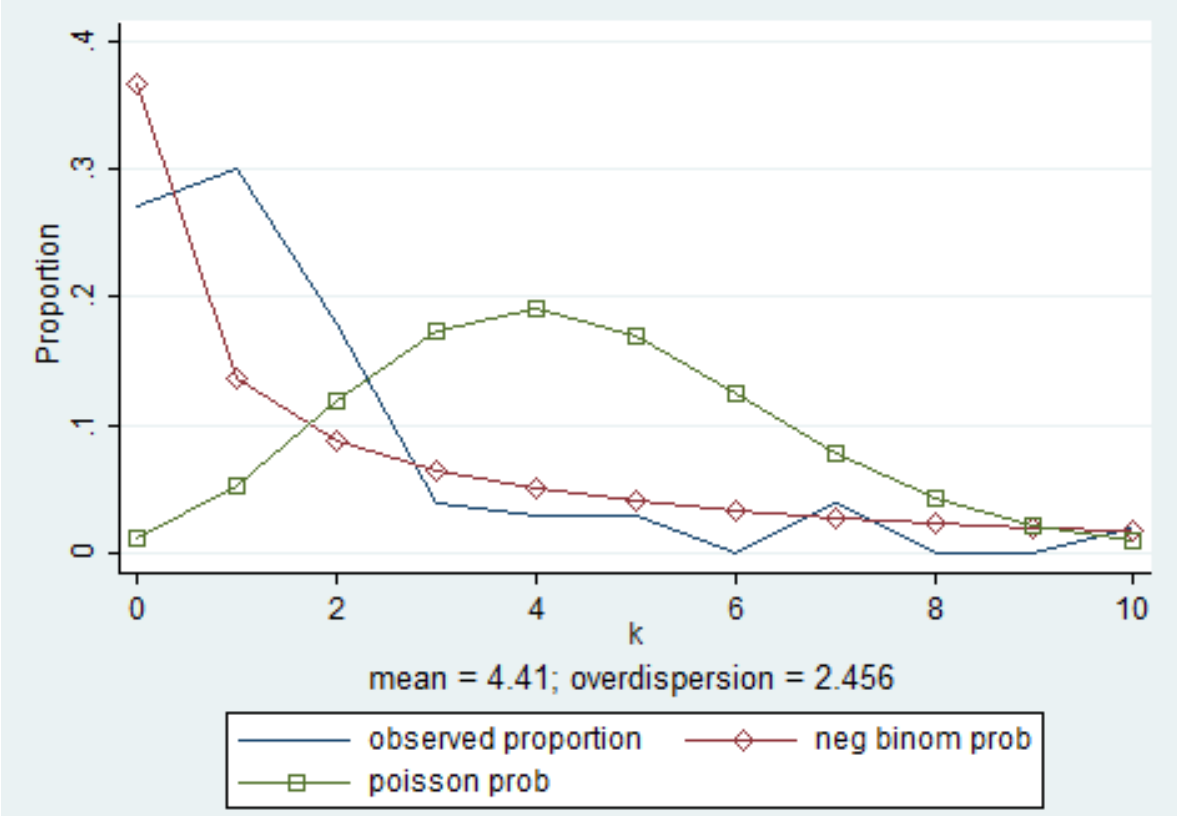

Figure 4. Distribution of count data for NBRM and PRM 
1 As Farla et al. (2016) argued, separating foreign investment from gross domestic capital formation is tricky and problematic in practice.

2 Keiretsu is a traditional Japanese corporation system, which is highly embedded in the Japanese economic, social and political context. It usually refers to the forms of interlocking business partnerships and crossshareholding of member companies in a highly organised and hierarchical system (Kimino et al., 2012). Keiretsu insulate member companies from financial fluctuations and hostile takeovers by foreign companies, which provides stable conditions for long-term strategic planning (Czinkota and Kotabe, 2000).

3 FDI measures the investment by foreign firms in domestic productive capacity which includes both preexisting capacity and non-existing capacity (Agosin and Machado, 2005). Greenfield FDI is the investment which is made only on non-existing capacity. For example, when existing foreign companies invest either their own assets or other companies' assets in the domestic market, their investment is calculated as FDI but not as greenfield FDI. China's official statistics do not distinguish greenfield and other FDIs while the fDi market focuses on greenfield FDI. This is the reason there are differences in the FDI data provided by these two sources.

4 The Orbis data only concern parent firms in China that have invested in shares in other Chinese firms (we excluded non-firm investors), while FDI Markets data concern foreign firms that invested in establishing subsidiaries in China. Corporate shareholding data representing ownership changes constitute a strong indicator of the effect of network relations generated by cross-territorial inter-firm DI in attracting FDI which is the research focus of the paper.

5 Of the 77 cities, not all are fully urbanized. Some hold tracts of underutilized or agricultural land within the city boundaries. However, inward FDI generally locates in urbanized areas, and can therefore be considered an agglomeration factor that would attract investment. Therefore, using the overall city size would bias the results, and instead Built Urban Area is used as a control.

6 Of the 77 cities used, there are big differences in urban population size. It can be expected that cities with large populations will on average attract more investment. Therefore, controlling for this ensures that the results are not biased. Given China's rapid urbanization, permanent residents (常住人口) rather than hukou holders (戶籍人口) is used to reflect local labour size.

7 GDP Index has been used as it best represents local market size and purchasing power. This is a common agglomeration factor used in measuring urban economic competitiveness. Therefore, to test the unbiased effect of the network indicators, the models must control for this.

8 There are three city levels in China's administrative system: county level, prefecture level, and provincial level. In the analysis, cities at prefecture and provincial level are defined as observations including four provincial cities (Beijing, Shanghai, Tianjin and Chongqing) and 73 prefecture cities.

9 In the star network pattern, one star node dominates the network while other nodes are connected only via the star node.

10 A sinker role denotes inward investments that outweigh outward investments. 
11 An outsider has outward investments that outweigh inward investments.

12 The company is the biggest financial investment company in Guangxi Province and it accounts for 80\% of outward DI projects. Qualitative research is needed to explore further how network position influences investment decisions.

13 Actors with a bridging role have the capacity to link unconnected parts of a network.

14 In 2014, 64\% of gross industrial output in Suzhou was produced by foreign firms (NBS, 2015). In addition, Suzhou has six export processing zones, which is largest number in China. 